IZA DP No. 10312

Marriage and Marriage Markets

Shoshana Grossbard

October 2016 


\title{
Marriage and Marriage Markets
}

\author{
Shoshana Grossbard \\ San Diego State University \\ and IZA
}

\section{Discussion Paper No. 10312 \\ October 2016}

\author{
IZA \\ P.O. Box 7240 \\ 53072 Bonn \\ Germany \\ Phone: +49-228-3894-0 \\ Fax: +49-228-3894-180 \\ E-mail: iza@iza.org
}

Any opinions expressed here are those of the author(s) and not those of IZA. Research published in this series may include views on policy, but the institute itself takes no institutional policy positions. The IZA research network is committed to the IZA Guiding Principles of Research Integrity.

The Institute for the Study of Labor (IZA) in Bonn is a local and virtual international research center and a place of communication between science, politics and business. IZA is an independent nonprofit organization supported by Deutsche Post Foundation. The center is associated with the University of Bonn and offers a stimulating research environment through its international network, workshops and conferences, data service, project support, research visits and doctoral program. IZA engages in (i) original and internationally competitive research in all fields of labor economics, (ii) development of policy concepts, and (iii) dissemination of research results and concepts to the interested public.

IZA Discussion Papers often represent preliminary work and are circulated to encourage discussion. Citation of such a paper should account for its provisional character. A revised version may be available directly from the author. 
IZA Discussion Paper No. 10312

October 2016

\section{ABSTRACT}

\section{Marriage and Marriage Markets}

This paper reviews models of marriage, with special emphasis on how the sex ratio (the ratio of marriageable men to women) can help explain measurable outcomes such as marriage formation, intra-marriage distribution of consumption goods, savings, labor supply, leisure, type of relationship, divorce, and intermarriage. Predictions are based on Demand and Supply analyses by Becker and the author. Evidence in support of the predictions is reported, most of it based on recent literature.

JEL Classification: E2, J11, J12, J16, J22, O15, R2

Keywords: marriage, marriage markets, sex ratio, savings, consumption, labor supply, cohort

Corresponding author:

Shoshana Grossbard

Department of Economics

San Diego State University

5500 Campanile Drive

San Diego, CA 92182

USA

E-mail:shosh@mail.sdsu.edu 
This paper reviews models of marriage, with special emphasis on how the ratio of marriageable men to women (the sex ratio) can help explain measurable outcomes such as marriage formation, intramarriage distribution of consumption goods, labor supply, savings, type of relationship, divorce, and intermarriage. I first present theories: Becker's in Section 2 and mine in Section 3. Evidence is presented in Section 4.

\section{Becker's models of marriage}

The first economic theory of marriage was authored by Gary Becker and consists of multiple models. At the micro-level of decision-making, the theory uses rational choice theory and models that have been applied in more conventional applications of economics. Becker's rational decisionmaker is motivated by gains or benefits, including the benefits of specialization between spouses (Becker 1973, 1981). Even though examples of such benefits given by Becker and others (e.g. Hoffman and Averett 2010, second edition) are phrased in terms of a marriage between a man and a woman, the benefits of specialization can also apply to same-sex couples with different skills. Other possible gains from marriage include opportunities to consume jointly and returns to scale.

Becker's economics of marriage also entails a level of analysis beyond the individual. Here Becker uses at least two types of model: Marshallian partial equilibrium models central to the tradition of Chicago Price Theory, and optimal sorting and matching models that are less typical of that tradition. ${ }^{1}$ The models with market-established prices simultaneously aim at explaining marriage formation and intra-marriage distribution based on the price dimension.

\subsection{Becker's market models of marriage}

In the Treatise on the Family Becker writes that he uses the phrase 'marriage market' metaphorically: it signifies that "the mating of human populations is highly systematic and structured." (Becker 1981, p. 39). Nevertheless, his marriage market models use the market concept in a more literal sense reminiscent of other applications of market analysis. Becker (1973), Section 4, assumes complete divisibility and negotiability of marital output and presents a demand and supply analysis with one type of man and one type of woman. Here markets are Marshallian markets in which prices serve as a mechanism for reaching allocative equilibrium and Demand and Supply curves are drawn. The ensuing market equilibrium implies both a marriage rate (the quantity axis) and a division of marital output (the price axis).

Becker's (1973) marriage market analysis starts with a simple competitive market model in which there are identical women (on one side of the market) and identical men (on the other side). In his original article on the economics of marriage (Becker 1973) presents a second Marshallian market equilibrium model. Even though this model was particularly important in his own eyes (Grossbard 2010) Becker dropped it from the Treatise (Becker 1981), Becker's widely cited book. This model is presented next.

\subsection{Becker's hedonic market model.}

This Marshallian market equilibrium model has multiple types of men and women participating in separate but inter-related marriage markets. In more modern terminology, this model can be labeled

\footnotetext{
${ }^{1}$ For more on Becker's theories of marriage and how they fit in the tradition of the Chicago School of Economics see Grossbard (2010).
} 
as a "hedonic" market model. ${ }^{2}$ Each market is composed of homogeneous women and homogeneous men and establishes an equilibrium price and quantity that depend e.g. on the number of participating men and women and on substitutability between various types of potential spouses. ${ }^{3}$

Figure 1, based on Fig. 2 in Becker (1973), models a market for a particular type of man $M_{i}$ and a particular type of woman $F_{j} \cdot{ }^{4}$ As in Becker's (1973) first model, men are on the supply side and women on the demand side. There are $(I-1)$ other types of men and $(J-1)$ other types of women. It is assumed that together an $\left(M_{i}, F_{j}\right)$ couple can produce marital output $Z_{i j}$. If men stay single their output is $Z_{i 0}$ and if women stay single their output is $Z_{0 j}$. Women's demand is downwardsloping: the more income/output women $F_{j}$ share with men $M_{i}$, i.e. the higher the price of this type of husband, the less women are interested in marrying them rather than marrying a man from a substitute type. Men's supply is upward-sloping: the larger the share of output (i.e. the higher the price) they get from this type of woman, the more men $M_{i}$ are likely to switch from other types of women to marry women $F_{j}$. All individual demands and supplies for these two types are aggregated and an equilibrium division of output $\left(m_{i j}\right)$ is obtained at the intersection of demand and supply, namely point $e_{0} . Z_{i j}=m_{i j}+f_{i j}$ and $Z_{i j}$ is given, and therefore this equilibrium also implies the price of women $f_{j i}$. At that point both men $M_{i}$ and women $F_{j}$ are satisfied being with each other rather than being in couple with a substitute of type $k$.

\subsection{Becker's sex ratio analyses}

Becker's marriage market analysis includes comparative statics showing that factors affecting marriage market conditions - including sex ratios-- are expected to influence division of marital output and income. This translates into predictions regarding effects of marriage market factors on each spouse's access to consumer goods. ${ }^{5}$ Effects on consumption were emphasized by the title of the section in which they were presented: 'the division of output between mates' (Becker 1973, Becker 1981, p. 42).

One of the most important testable implications of Becker's theory is the prediction that sex ratios, the ratios of men to women in a marriage market, affect individual consumption. Sex ratios shift aggregate demands and/or supplies in markets for mates. Therefore they can have an impact on the implicit price of wives and husbands. This follows from both Becker's simple marriage market model in Becker $(1973,1981)$ and from the hedonic market model in Becker (1973). The more men there are relative to the number of women, i.e. the higher the sex ratio, the more competition there will be among men and the higher women's price. This implies a higher share of marital output, and therefore individual consumption, obtained by women. ${ }^{6}$ The opposite is the case when there is relative oversupply of women. In the hedonic model with different types of men and

\footnotetext{
${ }^{2}$ Rao (1993) is possibly the first to have used the term 'hedonic' to describe this kind of multi-market Demand and Supply model of marriage. Also see Siow (2007). Some have called this Becker model a matching model (e.g. Abramitzky et al. 2011; Chiappori and Salanie 2016).

${ }^{3}$ The presentation of Becker's hedonic model of marriage follows Grossbard (2015a)

${ }^{4}$ Becker defines this market for women of type $i$. I follow the notation used by Choo and Siow (2006).

${ }^{5}$ What Becker calls "marriage market factors", i.e. the factors influencing equilibrium in marriage markets and therefore intra-household distribution of goods, appear as EEP in McElroy (1990) and as distribution factors in Chiappori (1997).

${ }^{6}$ According to the simple model division of output in a representative marriage is not clearly determined when there are equal numbers of men and women.
} 
women who are either substitutes or complements, changes in sex ratio in one marriage market can also affect prices, and access to marital output, in many other marriage markets. A higher aggregate sex ratio in the economy does not necessarily translate into a higher sex ratio in each $\left(M_{i}, F_{j}\right)$ marriage market.

In the Treatise Becker (1981) also presents a market analysis of sex ratio effects assuming identical men, identical women, and the possibility of polygyny. Here women are on the horizontal axis, in contrast to Becker's (1973) markets for husbands. Men's demand has a few steps, reflecting diminishing marginal productivity of plural wives. All of Becker's marriage market models lead to the same prediction of sex ratio effects on individual access to marital output or income: sex ratios will be directly related to women's share of marital income and their personal consumption in marriage. Becker $(1973,1981)$ suggests that to test this prediction empirically researchers may want to use information on what is now called 'assignable consumption', such as spending on husband's and wife's clothing, or leisure. In Becker's words: "available information on the amounts spent on husband's and wife's clothing or on their leisure time could be related to sex ratios, wage rates, education levels, and other determinants of the division of marital output." (Becker 1973; Becker 1981, p. 42). ${ }^{7}$

In a footnote he states that "an interesting start has been made" by Edward Lazear (in an unpublished 1978 memorandum) and by Mary J. Horney and Marjorie McElroy in a 1979 draft of McElroy and Horney (1981), one of the first bargaining models of marriage.

1.4 Becker on income and wage effects on consumption

McElroy and Horney (1981) became a widely cited article and fundamental contribution to the literature on intra-household allocation of consumption goods. Together with Manser and Brown (1980) McElroy and Horney (1981) inspired numerous empirical studies showing e.g. that his wage and income and her wage and income typically have different effects on assignable consumption of husband and wife (e.g. Thomas 1990, Wong 2015). A later strand of literature, the collective models such as Browning et al. 1994, have also added proofs that income and wage effects on personal consumption depend on whose income it is. Even though most of these models start out by criticizing some other Beckerian models of the family (the so-called unitary model that is not part of Becker's economics of marriage) they in fact confirm a prediction that Becker was the first to derive from an economic model.

\subsection{Becker's theory of marriage and the organization of household production}

Becker's market models of marriage all recognize that individuals can possibly have their own personal consumption. In other words he does not assume that they consume as one unit-i.e. there is no unitary consumption. However, in his marriage models Becker assumes that the household acts as a single 'firm' when organizing production in the household: it has a 'household' production function. The problem is that the theory does not specify who runs and organizes household production in a marriage or another multi-person unit. Who organizes the allocation of the time and money of the individual participants? If members of the family firm have different opinions or interests as to how their resources, including their own time, should be allocated to production inside or outside the home, how are conflicts resolved?

\footnotetext{
${ }^{7}$ In the Treatise this appears in a chapter entitled "Polygamy and Monogamy in Marriage Markets" It is Chapter 3 in Becker 1981 (first edition) and chapter 4 in Becker 1991 (second edition). The two editions of the Treatise are identical, except for the introductory chapter that Becker added in the second edition (Becker 1991).
} 
Is the household firm a collective? In collective farms, such as the kibbutzim in Israel, there used to be a 'work organizer' (sadran avoda) who determined who worked where. A general assembly was sometimes needed to determine whether a particular member was allowed to work outside of the collective. Does this have an equivalent in the 'household firm'? Or is the household a hierarchal firm, with a boss and a worker, and the boss makes top-down decisions? In the U.S. and many other countries under 'coverture' the right to manage the household's resources was given to the husband who also controlled the wife's earnings if she worked outside the home (see Geddes et al. 2012). In many mostly agricultural African countries it is still the case that women are not allowed to own land, which gives men much allocative decision-making power. In Western countries today it is often the case that couples chose an egalitarian lifestyle and a democratic organization of household production.

In Becker's theory of marriage these questions were pushed into the 'household production' black box. The same black box characterizes many more recent models of intra-marriage allocation such as bargaining models or consensus models (e.g. McElroy and Horney 1981, Apps and Rees 1997, Chiappori 1997). As pointed out in the next section this black box can be opened, at least partially, by relying on economic analysis of productive units more commonly studied by economists: firms and workers.

\section{Production in the bousehold with conflicts of interest}

The first economic model that recognizes the possibility of in-marriage conflicts of interest regarding household production is Grossbard (1976), an economic analysis of polygyny. It contains many of the same elements as Becker's marriage market models of marriage, but it models each wife and husband as a separate agent making decisions regarding production and consumption. This section presents a summary of my marriage market models, with an emphasis on later versions of the theory and testable implications. ${ }^{8}$

\subsection{A model inspired by labor economics.}

In labor economics firms and workers are typically considered as separate agents all alongbefore, during, and after employment. They often have conflicts regarding amount of work and compensation for that work. Even if there is a match between a worker and a firm and employment occurs the diverging interests that drive them may still lead to conflict. Similarly, when it comes to household production, I conceive of wives and husbands as separate agents who may have conflicting interests. In contrast to the case of conventional firms, in a marriage it is not always clear who is employer and who is worker: both men and women can possibly hire each other as household production workers, i.e. suppliers of 'Work-in-Household' (WIHO) (GrossbardShechtman 1984). There are multiple markets for such WIHO that set prices. ${ }^{9}$ In turn, these prices guide coordination and sorting, help resolve some conflicts of interest, and thus contribute to cooperation. Factors affecting marriage markets (including all the factors mentioned in Becker's theory of marriage) influence those prices.

Allocative efficiency is reached if quantity demanded equals quantity supplied at market WIHO price. Marriage institutions regulate (often informal) labor contracts between spouses, in a manner similar to how employment institutions regulate labor contracts between workers and employers (see

\footnotetext{
${ }^{8}$ For more details see Grossbard-Shechtman (1993) and Grossbard (2015b).

${ }^{9}$ Prices are called 'quasi-wage' in Grossbard-Shechtman $(1984,1993)$ and price of Work-In-Household (WIHO) in Grossbard (2015b).
} 
Grossbard-Shechtman and Lemennicier 1999), except that prices are more difficult to identify and measure. In Korea it was found that marriage made men happier than women and that this gender gap is more pronounced in older couples (Bethmann and Rudolf 2016). This is consistent with the idea that those who work at household production loose utility, that in Korea women do much more household production than men, that women may not be rewarded very well for their WIHO, that the gender gap in who does the WIHO is especially large for older couples, and that older women (who had few opportunities in the labor force) are especially underpaid for their WIHO.

\subsection{Sex ratio effects on labor supply}

In Becker's marriage market analysis any factor that shifts a demand or a supply of brides (or grooms) will have an impact on equilibrium price and quantity, and therefore on intra-household allocation of consumption goods. Factors that can influence marriage markets include wages for market labor, incomes, sex ratios, etc. These factors have also been incorporated in later theories of marriage, including mine. All price theories of marriage imply that ceteris paribus higher sex ratiosmore men around for a given number of women - lead to higher prices for women and lower prices for men in marriage markets.

A major prediction not found in Becker's marriage models is that sex ratios will affect individual labor supply outside the home (Grossbard-Shechtman 1984, Grossbard 2015b). Becker's marriage markets are markets for brides or grooms and in his theory higher sex ratios imply a higher price for brides which they can translate into more personal consumption goods and leisure.

However, he did not analyze allocation of time between three time uses: leisure, work in household production and work for an outside employer. ${ }^{10}$ In contrast, I conceive of marriage markets not as markets for people but as markets for work in household production benefiting the spouse (WIHO). So in the case of female heterosexual WIHO workers, higher sex ratios imply a higher price for the time that WIHO-working women spend working for the benefit of a man and a lower price for male WIHO. I assume that WIHO workers respond to prices and have an upward-sloping supply. Other motivations may be present, such as love, devotion, feelings of guilt or duty, but they don't neutralize the role of prices. Therefore, if women get paid better for their WIHO due to higher sex ratios they are less likely to participate in the labor force, whereas if sex ratios are lower male WIHO-workers will be less likely to work outside the home.

\subsection{Other predicted sex ratio effects}

Grossbard (2015b, Chapter 11) also analyzes how sex ratios may affect individual savings of men and women in different positions in life (single, married, or post-marriage). It integrates sex ratios into an overlapping-generations model that assumes a traditional gender-based division of labor and WIHO workers who get paid by their spouse for their work in household production. ${ }^{11} \mathrm{It}$ is predicted that a higher sex ratio will be associated with a higher savings rate among young single men and a lower savings rate among married men. In contrast, a higher sex ratio is predicted to lead to lower savings among single women and higher savings among married women. The net effect of sex ratios on aggregate savings rates will depend on which of these four effects dominate.

\footnotetext{
${ }^{10}$ Gronau (1977) did consider these three time uses but he completely ignored the supply side of household production. He only included demand for such production.

11 The overlapping-generations model of marriage and savings was first published as a working paper (Grossbard and Pereira 2010).
} 
Some relationships involve less commitment than marriage. For some purposes it is better to model markets for relationships involving cohabitation but not necessarily marriage. Whether couples are married or not can be viewed as an element of the price of WIHO defined in a broader sense (Heer and Grossbard-Shechtman 1981; Grossbard-Shechtman 1993). In a market for WIHO defined more broadly an element of the price of WIHO is the commitment that the employer of WIHO is willing to make to the WIHO worker. Under traditional gender roles this implies that the higher the price of women's WIHO the more men will be willing to make the marriage commitment. This also applies to men performing WIHO who are likely to prefer being married to the women they work for in household production. Have you heard of 'house boyfriends'? I have not, but I have heard of 'househusbands'.

Since higher sex ratios are associated with higher prices for female WIHO workers, it follows that when sex ratios are higher women will be more likely to be married rather than to cohabitate out-of-marriage. If men and women also differ in their preferences for divorce sex ratios may also affect divorce rates: with higher sex ratios women are more likely to get their divorce-related preferences fulfilled, and men less so.

Sex ratios may also affect the likelihood that a woman is a lone mother in the sense that her child is born in a single mother household. It was predicted in Ekert-Jaffe and Grossbard (2008) that there would be fewer lone mothers where sex ratios are higher and, presumably, women get 'paid' better for doing the WIHO of raising the child of her male partner.

Hedonic marriage markets for spouses with different characteristics coexist side by side. The higher a person's price in a marriage market the more they are likely to get their choice of partner. In the context of traditional gender roles, heterosexual relationships and coexisting ethnic or religious groups, the higher the sex ratio in the market for women with given characteristics, the more these women are likely to get their first choice of partner. More generally, individual WIHO-workers of given ethnicity or religion who prefer to marry inside their group are more likely to find a mate with that characteristic if their "price" is higher, and one of the reasons that price may be higher is due to fluctuations in sex ratio. In some cases intermarriage with a partner from a higher status group may be the preferred state, and the higher the price of the WIHO worker, the more that individual is likely to have their preference fulfilled (see Grossbard-Shechtman 1993).

Heer and Grossbard-Shechtman (1981) also used this marriage market model to explain why lower sex ratios would lead women to study more at universities: the more they expect to participate in the labor force the more they are likely to obtain an education that will raise their future earnings. Low sex ratios may also lead women to have fewer children and to be more likely to join feminist organizations (Heer and Grossbard-Shechtman 1981). Grossbard (1980) predicted that where sex ratios are lower it is more likely that polygyny (husbands marrying multiple wives) will be allowed. Otherwise, in societies where women have few options other than domestic production and reproduction, unmarried women or their relatives may put political pressure on those supporting the institution of compulsory monogamy and thereby making it difficult for some women to have their own children. Grossbard (1980) also presents a rationale that helps explain why some societies have polyandry, an institution allowing marriages with multiple husbands (usually brothers married to the same woman). These are early examples of 'institutional economics of marriage.' ${ }^{12}$

\footnotetext{
12 Another example of institutional economics of marriage can be found in Grossbard-Shechtman (1995) where some of the factors that help explain the passage of No-Fault divorce laws in the U.S. are discussed.
} 


\subsection{Compensating differentials in marriage}

The more others have a demand for WIHO workers with particular characteristics, the higher their price in marriage. In turn, this will affect all the outcomes discussed above: education, labor supply, type of relationship, intermarriage, etc. Furthermore, characteristics of those who employ WIHO will also affect the price of WIHO in a manner reminiscent of compensating differentials in labor markets. In the commercial sector, firms or industries with less desirable characteristics have to pay more for the same workers relative to what more desirable employers have to pay. Likewise, ceteris paribus the less attractive the characteristics of those employing WIHO the more they have to pay for WIHO. To the extent that women are doing the WIHO then compensating differentials are what men with less desirable characteristics have to pay beyond what the more attractive men are paying. For men doing WIHO compensating differentials will be expressed in extra pay for their WIHO when married to less desirable women. The idea of compensating differentials in marriage has many testable implications, including implications for the following outcomes: labor supply, time spent doing WIHO, marriage versus cohabitation, ethnic intermarriage, and number of wives in a polygynous society.

Examples of testable predictions regarding women's labor supply, assuming that women do the WIHO, are that women who are young relative to their husbands are likely to work less in the labor force (if they get a higher WIHO price than women older than their husbands; see GrossbardShechtman 1984) and that women who are thin relative to their spouses are likely to supply less labor to the labor force (Grossbard 2015b). It is also predicted that men who supply WIHO will get paid better if they are thinner relative to their wife and other men, and thus will be less likely to participate in the labor force.

Spouses who benefit from WIHO will be expected to pay more for WIHO if they are relatively old, uneducated, belonging to ethnic groups with lower status, or otherwise 'less desirable'. Therefore the presence of compensating differentials in marriage is predicted to lead to fewer hours of WIHO performed by the WIHO workers in the marriage if incomes are held constant.

As for the effect of education on the likelihood of cohabitation versus marriage, in a context of women as WIHO workers preferring a marriage contract, it is predicted that more educated women are more likely to be married than those with less education. The predicted effect of men's education is ambiguous when women are the main WIHO workers: on the one hand more educated men are more desirable mates and will be able to get away with paying a lower price for women's WIHO (thus being less willing to make commitments) but to the extent that jointly consumed goods are produced in marriage and these goods are normal goods, educated men may want to pay more for high quality WIHO (see Grossbard-Shechtman 2003).

\subsection{How central is specialization by gender to this theory?}

The essence of the WIHO concept is gender-neutral even though it was first developed in the context of a Nigerian society with rigid rules giving men numerous advantages over women. In Maiduguri, Nigeria, in the 1970s there were practically no labor markets for women, men owned the land and often had multiple wives, each living in her housing unit in a compound owned by the husband (Grossbard 1976). The Kanuris, Maiduguri's dominant tribe, traditionally have not permitted men to cook. Consequently the parallels between labor and WIHO were more transparent than they are in a contemporary Western country. It was also less of stretch to conceive of a price of WIHO in a cultural context where men were expected to provide food, lodging and clothing to their wife who would otherwise not have access to such necessities. Furthermore, anthropological studies have described conflicts of interest that often arose between a husband and his wife (wives) or 
between the wives working for the same husband with regard to the amount of compensation or the price of WIHO (e.g. Cohen 1971).

In the West today it is less clear who works at WIHO and who is the employer. The price of WIHO can take many more forms than satisfying a spouse's basic needs. In my writings since 1984 (including Grosssbard-Shechtman 1984 and Grossbard 2015b) gender neutrality prevails and assumptions regarding who does the WIHO are carefully stated. Grossbard and Jepsen (2008) make it clear that the theory also applies to same-sex couples and helps explain some differences between gays and lesbians. ${ }^{13}$ Nevertheless, given the predominance of heterosexual couples and women's larger role in household production relative to that of men (see Gimenez-Nadal and Sevilla-Sanz 2012) most recent empirical applications of marriage market models tend to focus more on women's role in household production or on the effects of marriage market conditions on women's labor supply.

\section{Evidence on sex ratio effects}

Sex ratios are expected to influence many aspects of our lives because they affect conditions in marriage markets. Evidence has been accumulating that this is indeed the case, the most reliable evidence being based on natural experiments such as exogeneous differences in sex ratio across birth cohorts or as a result of wars killing disproportionate numbers of men. Tests for sex ratio effects across geographical units such as cities are problematic due to the possibility of reverse causality. For example, when using cross-city variation to test for sex ratio effects on labor supply, self-selection needs to be taken into account: women may migrate to cities with more job opportunities for women, and men to where men have more good jobs. ${ }^{14}$ People can't change their year of birth and therefore examining the behavior of successive cohorts with varying sex ratios is a better way of testing for the consequences of sex ratio fluctuations.

Sex ratios vary by birth cohort because (1) on average, women marry men who are generally somewhat older and the age difference does not fluctuate much, and (2) the number of births fluctuates from one birth cohort to the next. For example, in the early 1950s in the USA there were more marriageable men than women - sex ratios higher than 1--as a result of declining numbers of births following the 1929 Depression. Conversely, in the mid-1960s, when the first baby-boomers started dating, baby-boom women were in oversupply as birth cohorts born right before them were relatively small and sex ratios were lower than 1 . Heer and Grossbard-Shechtman (1981) calculated that in the USA in 1956 the sex ratio was balanced but 9 years later, in 1965, there were 11 missing men for every 100 women ages 17 to 24 .

Evidence on sex ratio effects is reported in the order predictions were presented in the previous sections. Evidence is based on cohort-based variation, unless mentioned otherwise.

Consumption and Savings; Leisure. Tests of Becker's predictions regarding sex ratios effects on consumption and leisure were published many years after he published his seminal article. As he predicted, sex ratios are positively associated with the household's resources directed more towards the assignable consumption that women favor and away from that favored by men. Examples of such assignable consumption items are tobacco and alcohol consumed more by men and investments in children's human capital which tend to be higher on women's spending preferences

\footnotetext{
${ }^{13}$ Some have wrongfully stated that my theory limits women to the production of domestic commodities (e.g. Browning, Chiappori and Weiss 2014, p 128).

14 Therefore it is difficult to interpret the results reported by Grossbard-Shechtman and Neideffer (1997) or Chiappori et al. (2002) based on cross-city comparisons.
} 
(Duncan Thomas 1990; Brown 2009). In mainland China Maria Porter (2016) found that when sex ratios are higher men consume less tobacco and alcohol whereas sons are healthier (presumably because mothers invested more in their health capital.

As for sex ratio effects on leisure, another prediction of Becker, they were recently tested in Taiwan by Chang et al. (2016). They defined total work time as employment, commuting, and housework. They also compared three cohorts while also using cross-sectional data. They found evidence of sex ratio effects on husbands' and wives' share of leisure. As expected the higher the sex ratio the more leisure women had.

Sex ratio effects on savings have recently been tested by Shang-Jin Wei and Xiaobo Zhang (2011): they investigated recent changes in China's household savings as a function of the increasingly high sex ratio that China has been experiencing since male births have become an increasing proportion of all Chinese births. The sex ratio at birth in China climbed from 1.06 in 1980 (with 106 boys per 100 girls) to 1.27 in 2007, implying men outnumbering women at age 25 or below by at least 30 million. They found that increases in sex ratios account for about half of the observed increase in Chinese household savings in recent years. Horioka and TeradaHagiwara estimated how household savings varied with sex ratios in India and Korea using longterm time series data for the 1975-2010 period. They found that the pre-marital sex (or gender) ratio (the ratio of males to females) had a negative impact on savings in India, where the bride's side has to pay substantial dowries to the groom's side at marriage, but a positive impact in Korea, where, as in China, the groom's side has to bear a disproportionate share of marriage-related expenses including purchasing a house or condominium for the newlywed couple.

With Qingyuan Du, Wei also provided cross-country macro evidence based on data for 159 countries for the years 1990-2010 (Du and Wei 2013). They found that the more sex ratios diverge from 1 either positively or negatively the higher the savings rates. In addition, if the sex ratio is smaller than 1, i.e. there is a shortage of men in marriage markets, the savings rate is significantly higher.

Wei and Zhang (2011) and Du and Wei (2013) interpret their findings as evidence of a competitive savings motive. Wei, his co-authors, Becker and I all predict that when there is an excess number of men in the marriage market young men (or their parents) will have to compete more to find a wife. This will lead parents to save more and affect young men's savings. However, the different models consider different prices. In Becker $(1973,1981)$, the relevant price is the price of a bride or a groom; in the work of Wei and co-authors prices are paid before marriage, and mostly by parents. In addition, Grossbard and Pereira (2010) also consider the price of WIHO paid during the marriage which will have different effects on the savings of those who work in WIHO and those who don't.

Labor Supply. From 1960 to 1975 labor force participation rates of married women aged 20-24 rose dramatically: from 31.7 percent to 57.0 percent. ${ }^{15}$ This coincided with the entry of first babyboom women, born after World War II, into marriage and labor markets. By the late 1970s and early 1980s young women's employment surge stopped as later baby-boomers with more balanced sex ratios entered labor and marriage markets. Marriage market analysis implies that cohorts of women

\footnotetext{
${ }^{15}$ Detailed data on labor force participation by age and marital status only became available in 1965 . Using twenty years of such data Grossbard-Shechtman (1985) made it clearer that there is a negative correlation between sex ratios and young women's employment.
} 
born after 1960, when the number of babies born in the U.S. stopped booming, would have experienced a slowdown or a reversal in their rate of participation in the labor force and that the slowdown would accelerate when the small cohorts born in the early 1970s (around the passage of Roe vs. Wade) would reach adulthood. By the 1990s the women born after the baby-boom were old enough and the time series on labor force participation long enough to enable rigorous time series analysis tying women's labor supply to cohort-based changes in sex ratio. Using data for 1965-1990 and controlling for other factors that changed over time Grossbard-Shechtman and Granger (1998) showed that early baby-boom women experienced more rapid growth in labor supply than women born earlier or later. This was precisely the cohort with the lowest sex ratio.

As more data accumulated it became feasible to test for cohort-based sex ratio effects, including cohorts born before and after the first baby-boomers. Grossbard and Amuedo-Dorantes (2007) analyzed employment data for young women (aged 25 to 44) born between 1926 and 1980 over the period 1965-2005 and found that cohorts of women with lower sex ratios had experienced aboveaverage labor force participation whereas cohorts of women with higher sex ratios - such as women born during the baby-bust after 1961--had experienced below-average labor force participation. An increase in sex ratio of .10 was found to have the same effect on young women's labor force participation rate as two more years of schooling.

Marriage market analysis also helps explain recent trend in labor force participation. Consider the labor participation rate for all women ages 30 to 54 in three recent five-year periods: 2000 to 2005, 2005 to 2010, and 2010 to 2015. As shown in the dark blue line in Figure 2, overall during the period 2000 to 2015 that participation dropped, with a slight exception during the years immediately following the 2007 recession. The high sex ratio cohort born in 1961-1965 can be followed over that period. Let us call them the "Kennedy cohort," for their years of birth include the years of Kennedy's presidency. From 1961 to 1965 the number of births decreased from year to year, and therefore there were more men born on average in the years 1959 to 1963 than women born in 1961-65. We expect that with such high sex ratio the Kennedy women's labor force participation would be lower than that of other generations.

The light blue, yellow and green lines show what happened to women's labor force participation rate each time the Kennedy cohort replaced an earlier birth cohort in a particular age category. Each time the women of the Kennedy cohort entered an age group there was a bigger drop in participation. In the years surrounding the recession, when they entered ages 45 to 49, the Kennedy women's participation dropped even though there was a rise in the participation of all women ages 30 to 54 . As the Kennedy cohort reaches retirement it will be replaced by millenials born about fifteen years after the Kennedy cohort and characterized by relatively balanced sex ratios. Millenial women have demonstrated their commitment to the labor force by increasing their participation during the recession years. It is therefore to be expected that from the sex ratio point of view women's labor force participation in these age groups will increase (see Grossbard 2016).

More sex ratio effects. It follows from the analysis in the previous section that when sex ratios are higher and gender roles are traditional a higher sex ratio will be associated with relatively more marriage and fewer odds of non-marital cohabitation. This helps explain why the very low sex ratio cohort born after WWII in the US experienced rapid increases in non-marital cohabitation (Heer and Grossbard-Shechtman 1981, Guttentag and Secord 1983). Ekert-Jaffe and Grossbard (2008) found that the cohort of women born right after WWII in 12 Western countries in the years 1946 to 1952 and characterized by low sex ratios, were considerably more likely to become 
lone mothers. Using the Fragile Families study and cross-city variation in sex ratio, Mincy et al. (2005) found a positive association between sex ratio and the odds of a stronger commitment between parents. In particular, the higher the sex ratio, the higher were the odds of marriage versus other co-parentships not involving parental co-residence. They found that an increase of 10 percent in sex ratio, say from 1 to 1.1 --an extra 10 men per hundred women--, increases these odds of marriage by 14.1 percent.

As for the effect of sex ratios on the probability of intermarriage Chiswick and Houseworth (2011) found that in the USA the more members of the other gender from the same region of origin are available in a particular location, the less it is likely that an individual will intermarry, which indicates a preference for marrying people from the same origin.

Furthermore, Heer and Grossbard-Shechtman (1981) linked low sex ratios to large increases in women's college attendance, to the onset of the feminist revolution, and big drops in fertility. All these changes coincided with the entry of the lowest sex-ratio generation into markets for marriage and cohabitation in the late 1960s and 1970s (also see Grossbard-Shechtman 1993).

\section{Conclusion}

Analytical tools such as those that economists routinely apply to understand the determinants of more traditional outcomes can help us understand how marriage markets affect personal access to consumption goods, individual savings, leisure time, and labor supply. The same tools also throw light on choice of living arrangements, including choice between marriage and other forms of cohabitation and co-parenting, and investments in own and children's human capital.

Focus was centered on one particular variable reflecting marriage market conditions: the sex ratio, or ratio of men to women. By affecting demand and supply in marriage markets sex ratios can have an impact on numerous outcomes related to consumption, labor supply etc. Evidence on sex ratio effects was reported. Such effects are considerable. By affecting savings, labor supply and consumption sex ratios also have an impact on the macro economy.

\section{References}

Abramitzky, Ran, Adeline Delavande and Luis Vasconcelos (2011) Marrying up: the role of sex ratio in assortative matching. American Economic Journal: Applied Economics, 124-157.

Apps, Patricia and Ray Rees (1997), "Collective Labor Supply and Household Production." Journal of Political Economy 105:178-190.

Becker, Gary S. (1973), "A Theory of Marriage: Part I." Journal of Political Economy 81:813-846. (1981), A Treatise on the Family. Cambridge: Harvard University Press. Second Edition: 1991.

Bethmann, Dirk and Robert Rudolf (2016), "Happily ever after? Intrahousehold bargaining and the distribution of utility within marriage", Review of Economics of the Household, online first. 
Brown, P. H. (2009), "Dowry and Intrahousehold Bargaining: Evidence from China." Journal of Human Resources 44(1): 25-46.

Browning, Martin, Francois Bourguignon, Chiappori, Pierre-Andre, and Valerie Lechene (1994), "Incomes and Outcomes: A Structural Model of Intra-Household Allocation." Journal of Political Economy 102(6): 1067-1096.

Browning, M., P-A Chiappori and Y. Weiss (2014), Economics of the Family, Cambridge University Press.

Chang, S., Connelly, R. \& Ma, P. (2016), “What Will You Do If I Say 'I Do’?: The Effect of the Sex Ratio on Time Use within Taiwanese Married Couples" Population Research and Policy Review 35: 471-500.

Chiappori, Pierre-Andre (1997), "Introducing Household Production in Collective Models of Labor Supply." Journal of Political Economy 105:191-209.

Chiappori, Pierre-Andre, Bernard Fortin and Guy Lacroix (2002), "Marriage market, divorce legislation, and household labor supply." Journal of Political Economy 110: 37-71.

Chiappori, Pierre-Andre and Bernard Salanié (2016). "The Econometrics of Matching Models". Journal of Economic Literature 54(3): 832-61.

Chiswick, Barry R., and Christina Houseworth (2011), "Ethnic Intermarriage among Immigrants: Human Capital and Assortative Mating." Review of Economics of the Household 9: 149-180.

Choo, E., and A. Siow. (2006), "Who Marries Whom and Why." Journal of Political Economy 114(1): 175-201.

Cohen, Ronald. Dominance and Defiance. Washington: American Anthropological Association, 1971.

Du, Qingyuan and Shang-Jin Wei (2013). "A Theory of Competitive Saving Motive," Journal of International Economics 91: 275-289.

Ekert-Jaffe, Olivia and Shoshana Grossbard. (2008), "Does Community Property Discourage Unpartnered Births?" European Journal of Political Economy 24(1):25-40.

Geddes, Rick, Dean Lueck, and Sharon Tennyson. (2012), "Human Capital Accumulation and the Expansion of Women's Property Rights," Journal of Law \& Economics 55: 839-67 (November).

Gimenez-Nadal, J. I. \& Sevilla-Sanz, A. (2012), "Trends in Time Allocation: A Cross-Country Analysis." European Economic Review 56(6): 1338-1359.

Gronau, R. (1977), "Leisure, Home Production, and Work--The Theory of the Allocation of Time Revisited." Journal of Political Economy. 85:1099-124.

Grossbard, Amyra (1976), "An Economic Analysis of Polygamy: The Case of Maiduguri." Current Anthropology 17:701-7.

Grossbard, Amyra (1980), "The Economics of Polygamy" in J. DaVanzo and J. Simon (eds.), Research in Population Economics, Vol. II. Greenwich, CT: JAI Press. 
Grossbard, Shoshana (2010), "How 'Chicagoan' are Gary Becker's Economic Models of Marriage?" Journal of History of Economic Thought, 32(3):377-395.

. (2015a), "Sex Ratios, Polygyny, and the Value of Women in Marriage—a Beckerian Approach", Journal of Demographic Economics 81 (1): 13-25.

. (2015b), The Marriage Motive: A Price Theory of Marriage. Why Marriage Markets Affect Employment, Consumption and Savings. Springer.

Grossbard, Shoshana and Catalina Amuedo-Dorantes (2007), “Marriage Markets and Women's Labor Force Participation," Review of Economics of the Household 5:249-278.

Grossbard, Shoshana and Lisa Jepsen (2008), “The economics of gay and lesbian couples: Introduction to a special issue on gay and lesbian households." Review of Economics of the Household 6:311-326.

Grossbard, Shoshana and Alfredo M. Pereira (2010) "Will Women Save more than Men? A Theoretical Model of Savings and Marriage" CESifo Working Paper No. 3146, August.

Grossbard-Shechtman, S. (1984), "A Theory of Allocation of Time in Markets for Labor and Marriage." Economic Journal 94:863-82.

- (1985), "Marriage Squeezes and the Marriage Market." In Contemporary Marriage: Comparative Perspectives on a Changing Institution, edited by Kingsley Davis in association with A. GrossbardShechtman. New York: Russell Sage Publications.

Grossbard-Shechtman, Shoshana. (1993), On the Economics of Marriage. Boulder CO: Westview Press. . (1995) "Marriage Market Models" in M. Tommasi and K. Ierulli (eds.), The New Economics of Human Behavior. Cambridge: Cambridge University Press, 1995.

. (2003) "A Consumer Theory with Competitive Markets for Work in Marriage." Journal of Socio-Economics, 31(6): 609-645.

Grossbard-Shechtman, S. A. and C. W. Granger. (1998). "Women's Jobs and Marriage, Baby-Boom versus Baby-Bust," Population, 53: 731-52, (in French: Travail des Femmes et Mariage du babyboom au baby-bust").

Grossbard-Shechtman, S.A. and Bertrand Lemennicier. (1999) "Marriage Contracts and the Law-andEconomics of Marriage: an Austrian Perspective," Journal of Socio-Economics, 28: 665-690.

Grossbard-Shechtman, Shoshana and Matthew Neideffer (1997). "Women's Hours of Work and Marriage Market Imbalances," in Economics of the Family and Family Policies, edited by Inga Persson and Christina Jonung, London: Routledge.

Guttentag, Marcia and Secord, Paul F. (1983), Too Many Women: The Sex Ratio Question. Beverly Hills: Sage Publications.

Heer David M. and Amyra Grossbard-Shechtman (1981), "The Impact of the Female Marriage Squeeze and the Contraceptive Revolution on Sex Roles and the Women's Liberation Movement in the United States, 1960 to 1975." Journal of Marriage and the Family 43:49-65. 
Hoffman, Saul D. and Susan L. Averett (2010), Women and the Economy, second edition. Boston: Addison-Wesley.

Horioka, Charles Yuji and Akiko Terada-Hagiwara (2016), “The Impact of Sex Ratios before Marriage on Household Saving in Two Asian Countries: The Competitive Saving Motive Revisited." Review of Economics of the Household, online first.

Manser, Marilyn and M. Brown (1980), "Marriage and Household Decision Making: a Bargaining Analysis." International Economic Review 21:31-44.

McElroy, Marjorie B. (1990), “The Empirical Content of Nash-Bargained Household Behavior.” The Journal of Human Resources 25: 559-583.

McElroy, Marjorie B., and Mary J. Horney. 1981. "Nash bargained household decisions: toward a generalization of the theory of demand." International Economic Review, 22: 333-349.

Mincy, Mincy, Shoshana Grossbard and Chien-Chung Huang "An Economic Analysis of CoParenting Choices: Single Parent, Visiting Father, Cohabitation, Marriage”, EconWPA papers in Labor and Demography \#0505004, May 2005.

Porter, Maria (2016), "How Do Sex Ratios in China Influence Marriage Decisions and IntraHousehold Resource Allocation?" Review of Economics of the Household 14(2): 337-371.

Rao, V. (1993), "The Rising Price of Husbands: A Hedonic Analysis of Dowry Increases in Rural India." Journal of Political Economy 101(4): 666-677.

Siow, Aloysius (2007) Communication by email to the author, October 30.

Thomas, Duncan (1990). "Intra-household Resource Allocation: An Inferential Approach." Journal of Human Resources 25:635-664.

Wei, Shan-Jin and Xiaobo Zhang (2011), "The Competitive Savings Motive: Evidence from Rising Sex Ratios and Savings Rates in China," Journal of Political Economy 119 (3): 511-564.

Wong, Edwin (2015), "Marital Bargaining in the Demand for Life Insurance: Evidence from the Health and Retirement Study" Review of Economics of the Household 13: 243-268. 


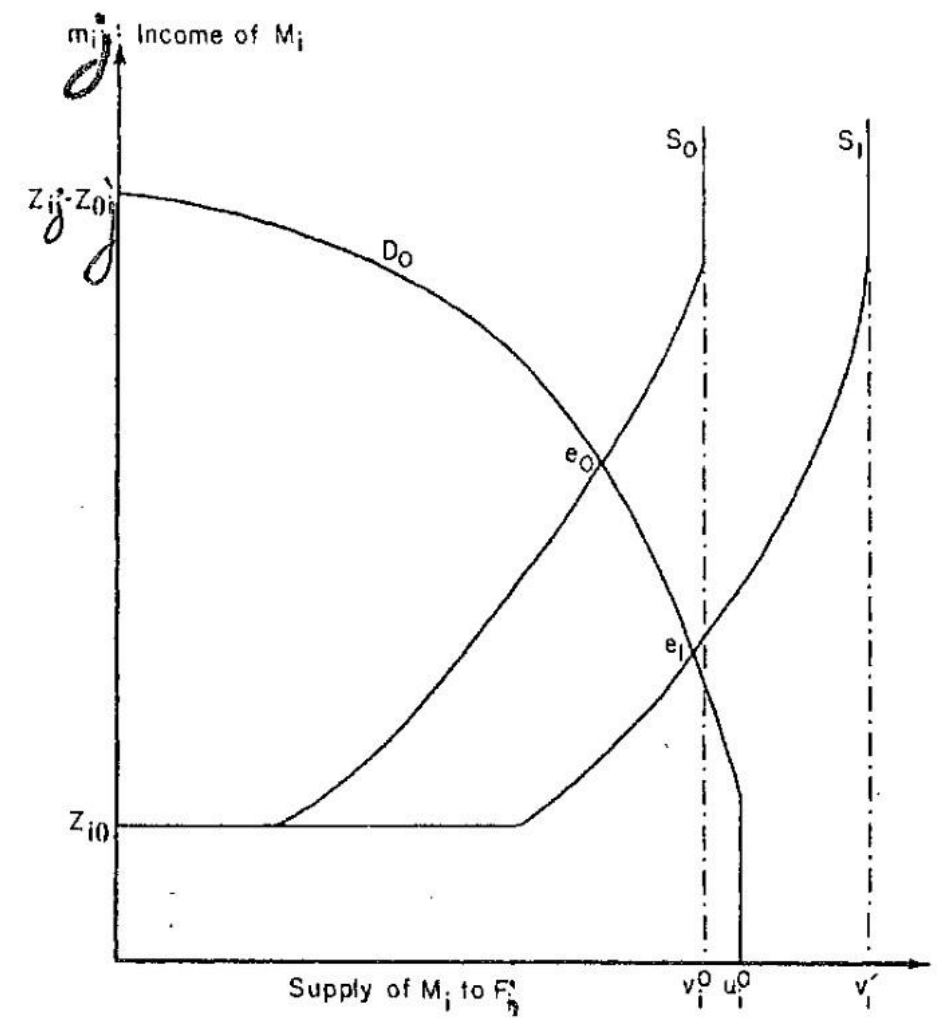

Figure 1. Becker's market for men $M_{i}$, with demand by women $F_{j}$ 


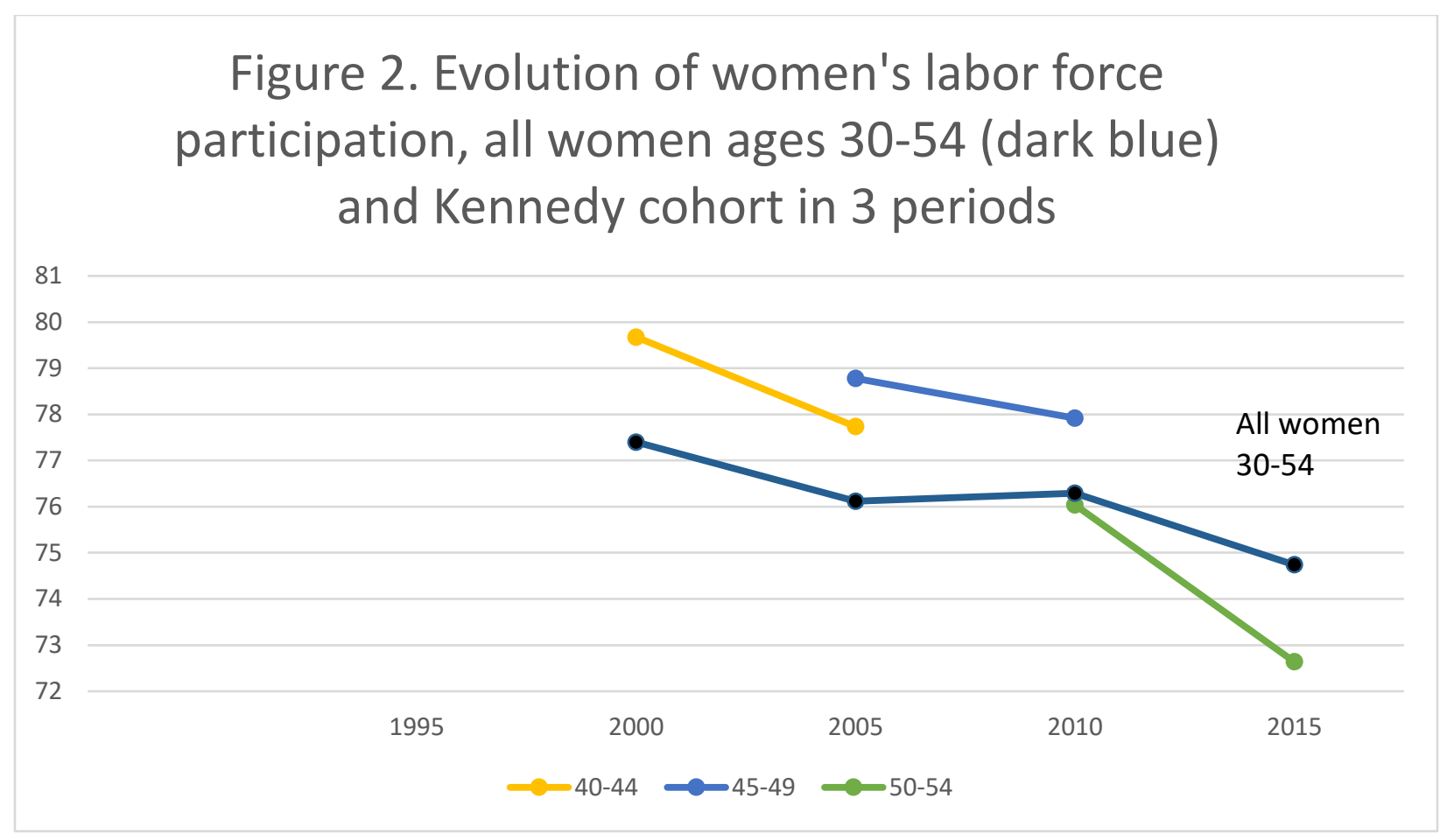

Note Whenever they are compared to all women ages 30-54 the Kennedy women experienced a faster drop in participation within the 5 -year period 